\title{
Design the SLA of SIAKAD Based on CMMI- SVC and ITILV3 Framework
}

\author{
Rachmah Agus Putri ${ }^{1}$ and Raden Vinantius Hari Ginardi ${ }^{1}$
}

\begin{abstract}
PTIPD is an IT support at UIN Malang, responsible for information technology. Have the vision to apply and develop information technology to realize a university as Cyber Campus and Cyber Community and mission which is to provide services to the academic community in the utilization of Information Technology. One of the information system services that play an important role is SIAKAD. So far the services of SIAKAD have not fully met the criteria from vision and mission made by PTIPD. Technical related problems often happen repeatedly and the job description is not organized. The problems above more or less shows that the quality and performance from SIAKAD service has not met the standard to support the vision and mission of PTIPD. The researcher used work method which is CMMI-SVC related to capability measurement, related to technical problem and Service Level Agreement (SLA) design based on ITIL V3 framework and FMEA method in weighing the value of SLA elements. The first thing to do is mapping the criteria and CMMI-SVC's processes area, and then measured the capability level of the selected process area, after that is design of the SLA used ITIL V3 best practices and SLA's weight calculations used FMEA method. The result of the capability level shows level 0 , which is the basic thing that must be met to reach level 1 is the existence of SLA. This thesis produced a design of Service Level Agreement document.
\end{abstract}

Keywords-CMMI-SVC, ITIL V3, FMEA Method, Service Design, Service Level Agreement.

\section{INTRODUCTION}

One of the information systems which play an important role is SIAKAD. SIAKAD is the academic information system that is operated by the college students in everything related to the academic. So far SIAKAD service has not fully met the criteria from vision and mission set by UIN Malang. Frequently a same problem occurs and the management of Human Resources is not well organized. Examples of problems happened from the side of SIAKAD are: (1) when Study Plan Card's access to SIAKAD can only be done within the scope of university since 2015 , from interview result more or less 100 college students argue to experience difficulties with this because during the process of SIAKAD is hard to access and trouble, (2) frequent trouble, college students cannot access SIAKAD during the process of Study Plan Card, (3) Human Resources management that hasn't been organized and not

${ }^{1}$ Rachmah Agus Putri and Raden Vinantius Hari Ginardi are with Departement of Business Management and Technology, Institut Teknologi Sepuluh Nopember, Surabaya, Indonesia. Email: rachmah.ap@gmail.com; hari.ginardi@gmail.com. written in document causes the responsibility of job description still a mess. The problem above related to technical problems and internal organization problem and PTIPD.

The problem above more or less shows that the quality from Academic Information System services and Human Resources management not according to standards to support vision and mission of PTIPD UIN Malang. The researcher used work method which is CMMI-SVC related to capability measurement, and then related to technical problem and Service Level Agreement (SLA) document making based on ITIL V3 framework and FMEA method for value weighing of each SLA component.

The results issued or output from this research is to produce a design SLA document, why does UIN Malang need SLA? To anticipate that mistake above, and in order to improve performance from SIAKAD service when Student Plan Card takes place, to prevent a same mistake to occur again that inhibit the process of Student Plan Card (KRS), therefore this research produces the design of SLA document, which this SLA become the reference for SIAKAD and which must be fulfilled by the party of PTIPD to BAAK and vice chancellor III related to SIAKAD service.

\section{LITERATURE REVIEW}

\section{A. CMMI (Capability Maturity Model Integration)}

The Capability Maturity Model Integration (CMMI) is a set of best practices that is recognized globally which allows the organization to improve performance, main ability or capability, and important business process.

CMMI is an effective and integrated process improvement model, which is a collection from best practices of various industries. Many organizations have successfully used CMMI to create high quality software by improving the manufacturing processes. That organization becomes better in terms of scheduling and financing, productivity, quality, customer satisfaction, and return on investment[1]. CMMI basically is a constellation that is consisted of CMMI for Development (CMMI-DEV), CMMI for Acquisition (CMMI - ACQ) and CMMI for Services (CMMI-SVC). In the next development, these three constellations are then combined with CMMI only, with 5 maturity stages and adopted 22 process key areas. The 5 maturity stages of CMMI are:

1) Stage 0 is called Incomplete

2) Stage 1 is called Performed 
3) Stage 2 is called Managed

4) Stage 3 is called Defined

5) Stage 4 is called Quantitatively Managed

6) Stage 5 is called Optimizing.

\section{B. CMMI-SVC (CMMI for Service)}

CMMI-SVC focuses on service delivery not to development. This CMMI-SVC is more intended for a product with no forms (services) and non-storable, like Information Technology Services, transportation, health, training, and consultation[2]. CMMI model for Service provides guides to improve the organization's ability to provide quality service for customers and end users. This best practice helps the organization to provide superior service by strengthening weak customer contact points and improve customer's experience. Each process area has its own goal and practice. CMMI-SVC has 24 process areas, will be shown in the following table:

TABLE 1.

CMMI-SVC PROCESS AREA

\begin{tabular}{|c|c|c|}
\hline Area Process & Category & Maturity Level \\
\hline $\begin{array}{l}\text { Capacity and Availability } \\
\text { Management (CAM) }\end{array}$ & Project Management & 3 \\
\hline $\begin{array}{l}\text { Causal Analysis and Resolution } \\
\text { (CAR) }\end{array}$ & Support & 5 \\
\hline $\begin{array}{l}\text { Configuration Management } \\
\text { (CM) }\end{array}$ & Support & 2 \\
\hline $\begin{array}{l}\text { Decision Analysis and } \\
\text { Resolution (DAR) }\end{array}$ & Support & 3 \\
\hline $\begin{array}{l}\text { Integrated Project Management } \\
\text { (IPM) }\end{array}$ & Project Management & 3 \\
\hline $\begin{array}{l}\text { Incident Resolution and } \\
\text { Prevention (IRP) }\end{array}$ & $\begin{array}{l}\text { Service Establishment } \\
\text { and Delivery }\end{array}$ & 3 \\
\hline Measurement and Analysis & Support & 2 \\
\hline $\begin{array}{l}\text { Organizational Innovation and } \\
\text { Deployment (OID) }\end{array}$ & Process Management & 5 \\
\hline $\begin{array}{l}\text { Organizational Process } \\
\text { Definition (OPD) }\end{array}$ & Process Management & 3 \\
\hline $\begin{array}{l}\text { Organizational Process Focus } \\
\text { (OPF) }\end{array}$ & Process Management & 3 \\
\hline $\begin{array}{l}\text { Organizational Process } \\
\text { Performance (OPP) }\end{array}$ & Process Management & 4 \\
\hline Organizational Training (OT) & Process Management & 3 \\
\hline
\end{tabular}

C. ITIL (Information Technology Infrastructure Library)

ITIL is a series of concepts and infrastructure management techniques, development, and information technology operation (IT). ITIL is published in a book series which each discusses a management topic of IT. ITIL provides a trusted guide about how business can use
IT service to support their purposes and facilitate business growth[3].

ITIL focuses itself on continuous measurement and IT service management improvement, either from business perspective or customer. ITIL has a function to map IT management service level, and has nine processes, which is issued by OGC (Office of Government Commerce). That ITIL V3 lifestyle is consisted of Service Strategy, Service Design, Service Transition, Service Operation, and Continual Service Improvement.

\section{SLA (Service Level Agreement)}

SLA stands for Service Level Agreement. SLA is an agreement form between customer business and IT provider. The definition of SLA is a part of the service agreement overall between two entities for performance improvement or delivery time must be fixed during the cooperation contract period. The components in SLA usually called element support, for example the expected time respond, escalation procedure, services ability. It is expected that with SLA it can makes IT service better. Here are the elements or components in making SLA[4]:

1) Preliminary

2) IT Purpose

3) IT Service

4) Limitations and Scope

5) Service Working Time

6) Service availability

7) Service reliability

8) Service performance

9) Customer Service and Problem Escalation

10) Change Management

11) Security

12) Report and Review of IT service

\section{E. FMEA Method}

FMEA is a technique used to identify, prioritize, and reduce problems from the system, design, or process before that problem occurs. Besides that, FMEA is a methodology designed to identify potential failure mode for a product or process before happens, consider related risks to that failure mode, identify and implement corrective actions to overcome the most important problem. The purpose of FMEA is to determine the level of risk from each failure type.

This FMEA is also used to suppress losses incurred because of production process failure or product failure when used by the users, the ways are as follows: identify possible failures, give priority scale from each failure type and take corrective action. Each risks and impacts of the design, function, and product process has been studied overall ( $\mathrm{S}=$ Severity), failure possibility $(\mathrm{O}=$ Occurrence), how far can it be detected ( $\mathrm{D}=$ Detection). From this assessment has also been studied about the cause and control. The end result is total value in the form of RPN (Risk Priority Number) which shows total number of votes from the aspect of S, O, D. Risk Priority Number is the 
result from multiplication of severity, occurrence and detection level value $(\mathrm{RPN}=\mathrm{S} \times \mathrm{O} \times \mathrm{D})$. The higher the value of RPN is, the higher the need to take an action. Rating scale 1-10, RPN maximum $=1000(10 \times 10 \times 10$ from occurrence, detection, and severity value). $99 \%$ from 1000 is 990 , then the limitation of RPN $=1000-990=10$. Therefore for $99 \%$ the confidence level of RPN limitation is $10[5]$.

\section{Methodology}

This chapter will discuss about the research steps described in a flow diagram like presented in Figure 3 below:

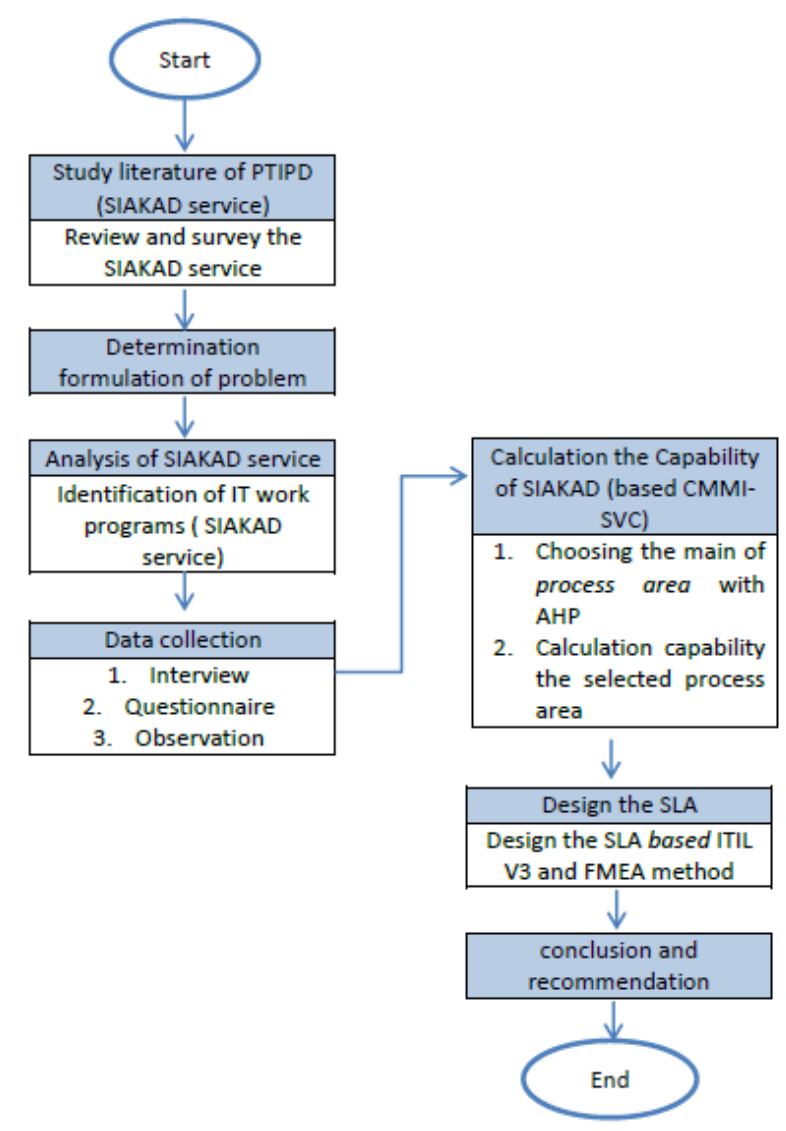

Figure 3. Research Flow

\section{A. Mapping of Academic System Information Process}

Mapping is done by comparing relevant CMMI-SVC with business process at PTIPD. The result is summarized in a table that loads some process areas associated with research theme. The area process table is analyzed to get area process priority that describes studied business process.

\section{B. Determination of Area Process and CMMI-SVC Capability Level}

This step aims to get the most relevant area process with the research theme. The respondent writes down the level of importance of each area process to other area process that has been grouped based on CMMI-SVC capability level. The valuation uses likert scale with value 1 until 9 which shows the level of importance of one process to other process. The questionnaires are distributed to respondents who have been identified on RACI Chart.

Then the determination of relevant area process and capability level is done by using Analytical Hierarchy Process (AHP) decision making method by firstly compiling questionnaire results obtained in the form of comparison matrix. The final result of AHP process is weight for each area process. Area process with highest weight is chosen as an area process to measure it is capability level.

\section{Design Service Level Agreement (SLA)}

After obtaining data, then identification of service needs is done by doing survey and questionnaires distribution to related staff in relation with SIAKAD services. The data obtained will be used as the basis in designing Service Level Agreement document. The following is the selection design of Service Level Agreement which can be seen in table 3 .

TABLE 3.

ELEMENTS OF SERVICE LEVEL AGREEMENT

\begin{tabular}{cll}
\hline \hline Structure & \multicolumn{1}{c}{ Elements } \\
\hline & 1. & Preliminary \\
& 2. & IT Purpose \\
& 3. & IT service (SIAKAD) \\
Minimal Structure & 4. & Limitations and scope \\
& 5. & Service availability \\
& 6. & Service reliability \\
& 7. & Service performance \\
& 8. & Report of IT Service \\
\hline \hline
\end{tabular}

The assignment of weight values per elements above is based on FMEA method. Each cause of failure per component the rating value will be different. There are severity, occurrence, and detection variables in FMEA method, each variable has it is own table and rating from number 1-10 and each rating has it is definition.

\section{RESULT AND DISCUSSION}

\section{A. Determination of CMMI-SVC Area Process}

In the determination of criteria and CMMI-SVC process area which it's capability will be measured, calculation with AHP method will be used, and there is a questionnaire filled by the respondents in accordance with the result of RACI Chart, the total of respondents is 8 people, then the total of questionnaires is 24 questions. The following figure 4 is the hierarchy from process area determination and criteria and process area from CMMI-SVC: 


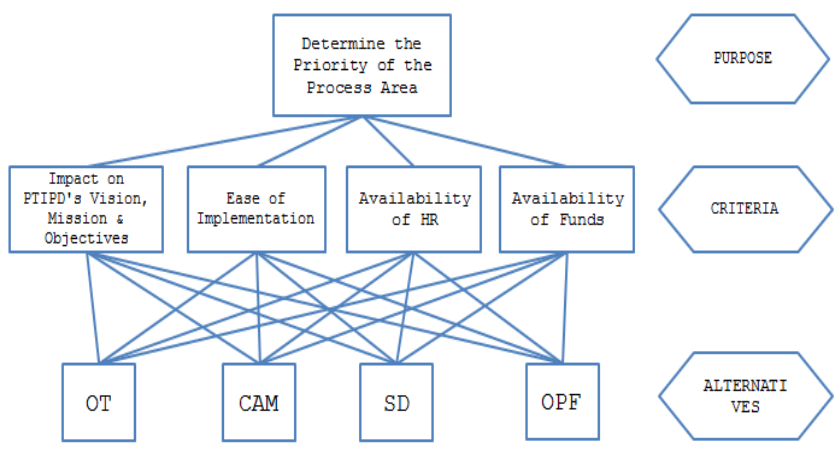

Figure 4. The Hierarchy of Determination of CMMI-SVC Area Process Priority

\section{B. Determination of Area Process Priority}

Determination of area process priority to each criteria generates different result. The process area with highest priority on the criteria of Impact to Vision, Mission, and Business Objective, Ease of Implementation criteria, Availability of highest priority Human Resources achieved by SD (Service Delivery), and Availability of highest priority fund achieved by CAM. The determination of area process priority wanted to be measured in this research calculates all criteria. Therefore, once again total weights from all area process is calculated by using excel to help the calculation of total weights from each alternatives. The weight of total alternatives is obtained from the addition of all multiplication between alternatives weight of each criteria with related criteria weight. Table 4 shows the result of total alternative calculation.

Table 4 shows that Service Delivery Area Process has the most total weight between other area process. The priority of area process in sequence from the most weight is SD $(1,21)$, CAM $(1,18)$, OPF $(0,84)$, and OT $(0,41)$. The ratio of inconsistency overall is $0,095(\leq 0,10)$ which means that according to Saaty the calculation result of AHP overall, can be trusted. It can be concluded that Service Delivery area process (Service) is set as CMMI-SVC area process which it's capability level will be measured.

\section{Calculation of SIAKAD Capability}

After getting process area priority which will be measured, then interview to respondents whose result will be used to support weight value assignment on questions in relation with the service delivery process area. The result from calculation, shows that Academic System Information capability level is on level 0 , which shows that the process available inside that area of Academic System Information service has not yet run completely by the company, the Table 5 shows the total calculation result of SIAKAD capability level.

In the Specific Goals of 1, SP 1.1, and SP 1.2 still have NI rating, which shows the conclusion that there is no service agreement implementation for IT service, which is Academic System Information service, in this case regulatory basics related to Academic System Information service has not been implemented. In the Specific Goals of 2, SP 2.1 until SP 2.3 sequentially have rating NI, PI, and NI, which means that IT service approach has been done and only some are documented but not in official document, and still lack in preparation stage and the demand management system shown with incomplete work product SP 2.2 and 2.3. In the Specific Goals of 3, SP 3.1 until SP 3.3 gets rating NI, NI, and PI. In the assessment of Generic Goals 2, averagely get rating NI and PI has not reached rating LI. Meanwhile in the Generic Goals of 3, GP 3.1 and .2 only reaches rating NY and NI. The assessment result shows that Generic Goals 3 has not obtained rating Satisfied, then the capability level of level 3 is not achieved. Generic Goals 2 has not obtained rating Satisfied, so that the capability level of level 2 is not achieved. Meanwhile Generic Goals 1 also has not obtained rating Satisfied, so that the capability level of level 1 is also not achieved. Therefore the assessment of capability level shows that Academic System Information service still reaches capability of level of level 0 , because is still unable to fulfill practices on Generic Goal of 1 until 3 completely with FI or LI status.

TABLE 4.

The Calculation of Area Process Total Alternative Weight

\begin{tabular}{ccccccccc}
\hline \hline & \multicolumn{7}{c}{ Criteria } & \multicolumn{7}{c}{ Area Process } \\
\cline { 1 - 6 } No & Criteria Name & Weight & OT & CAM & SD & OPF & & \\
\hline 1 & K1 & 0,52 & 0,11 & 0,36 & 0,41 & 0,12 & 1 & $0,015(1 \%)$ \\
2 & K2 & 0,21 & 0,11 & 0,24 & 0,45 & 0,20 & 1 & $0,034(3 \%)$ \\
3 & K3 & 0,16 & 0,12 & 0,20 & 0,49 & 0,20 & 1 & $0,028(3 \%)$ \\
4 & K4 & 0,11 & 0,07 & 0,38 & 0,24 & 0,32 & 1 & $0,018(2 \%)$ \\
& Total & 1,00 & 0,41 & 1,18 & 1,21 & 0,84 & & $0,095(10 \%)$ \\
\hline \hline
\end{tabular}


TABLE 5 .

SuMmary of CAPABILITY RESUlt VALUe FROM SERVICE DELIVERY AREA PROCESS

\begin{tabular}{|c|c|c|c|}
\hline Goals & Practices & Score & Rating \\
\hline \multirow[t]{2}{*}{ SG 1} & SP 1.1 & 2 & $\mathrm{NI}$ \\
\hline & SP 1.2 & 2 & NI \\
\hline \multirow[t]{3}{*}{ SG 2} & SP 2.1 & 2 & NI \\
\hline & SP 2.2 & 3 & PI \\
\hline & SP 2.3 & 2 & NI \\
\hline \multirow[t]{3}{*}{ SG 3} & SP 3.1 & 2 & NI \\
\hline & SP 3.2 & 3 & PI \\
\hline & SP 3.3 & 3 & PI \\
\hline \multirow[t]{10}{*}{ GG 2} & GP 2.1 & 2 & NI \\
\hline & GP 2.2 & 3 & PI \\
\hline & GP 2.3 & 3 & PI \\
\hline & GP 2.4 & 2 & NI \\
\hline & GP 2.5 & 2 & NI \\
\hline & GP 2.6 & 2 & NI \\
\hline & GP 2.7 & 2 & NI \\
\hline & GP 2.8 & 3 & PI \\
\hline & GP 2.9 & 2 & NI \\
\hline & GP 2.10 & 3 & PI \\
\hline \multirow[t]{2}{*}{ GG 3} & GP 3.1 & 1 & NY \\
\hline & GP 3.2 & 2 & NI \\
\hline
\end{tabular}

\section{Calculation of SLA Weight}

After doing the calculation of Service Delivery process area capability level, which shows that Service Delivery process area is in level 0 . The basic thing to reach level 1, first is with SLA document for Academic System Information service, so that with SLA, the achievements in next level can be fulfilled by PTIPD party in relation with Academic System Information service. In this sub chapter the weighting of SLA value will be discussed which will be presented in the form of table 6 . The weighting of each elements is based on FMEA (Failure Mode and Effect Analysis) method.

Assigning weight values per component above is based on FMEA method. The rating value of each cause of failure element will be different in accordance with the criteria of FMEA method. Table 7 below discusses about the risk elements and also indicators which weight will be valued, and in table 8 the calculation result of RPN each elements.
Several SLA elements that can be calculated using the FMEA method are service availability, service reliability, and service performance. This aims to determine the SLA value that must be met by the SIAKAD service when KRS. The data obtained is based on brainstorming, discussion group forum.

TABLE 6.

ELEMENTS OF SLA DESIGN

\begin{tabular}{cll}
\hline \hline Structure & \multicolumn{2}{c}{ Elements } \\
\hline & 1. & Preliminary \\
& 2. & IT Purpose \\
& 3. & IT service (SIAKAD) \\
Minimal Structure & 4. & Limitations and scope \\
& 5. & Service availability \\
& 6. & Service reliability \\
& 7. & Service performance \\
& 8. & Report of IT Service \\
\hline \hline
\end{tabular}

TABLE 7. INDICATORS OF SLA ELEMENTS RISKS

\begin{tabular}{lrl}
\hline \hline \multicolumn{1}{c}{ Risk Factor } & \multicolumn{1}{c}{ Risk Indicator } \\
\hline Service Availability & 1. & $\begin{array}{l}\text { Academic System Information } \\
\text { service is not fully 24 hours } \\
\text { available when Study Plan Card. }\end{array}$ \\
& 2. $\begin{array}{l}\text { SIAKAD service when Study } \\
\text { Plan Card can only be accessed in } \\
\text { campus area, otherwise can't. }\end{array}$ \\
\hline Service Reliability & 3. $\begin{array}{l}\text { SIAKAD service often } \\
\text { experiences trouble or down } \\
\text { system when Study Plan Card. }\end{array}$ \\
\hline Service Performance & 4. $\begin{array}{l}\text { SIAKAD service does not run in } \\
\text { accordance with it is function } \\
\text { which is Study Plan Card runs } \\
\text { optimally. }\end{array}$ \\
\hline \hline
\end{tabular}

TABLE 8. CALCULATION OF RPN

\begin{tabular}{|c|c|c|c|c|c|c|}
\hline Risk Factor & Risk Indicator & $\mathrm{S}$ & $\mathrm{O}$ & $\mathrm{D}$ & RPN & Rating \\
\hline \multirow{3}{*}{$\begin{array}{l}\text { Service } \\
\text { Availability }\end{array}$} & Academic $\quad$ System & 7 & 6 & 5 & 210 & 3 \\
\hline & $\begin{array}{l}\text { Information service is not } 24 \\
\text { hours available when Study } \\
\text { Plan Card. }\end{array}$ & & & & & \\
\hline & $\begin{array}{l}\text { Academic System } \\
\text { Information when Study Plan } \\
\text { Card can only be accessed in } \\
\text { campus area, otherwise can } \\
\text { not. }\end{array}$ & 7 & 7 & 5 & 245 & 2 \\
\hline $\begin{array}{l}\text { Service } \\
\text { Reliability }\end{array}$ & $\begin{array}{l}\text { Academic } \\
\text { Information service often } \\
\text { experiences trouble or down } \\
\text { system when Student Plan } \\
\text { Card. }\end{array}$ & 7 & 8 & 5 & 280 & 1 \\
\hline $\begin{array}{l}\text { Service } \\
\text { Performance }\end{array}$ & $\begin{array}{l}\text { Academic } \\
\text { Information service does not } \\
\text { run in accordance with it's } \\
\text { function which is running } \\
\text { optimally when Study Plan } \\
\text { Card. }\end{array}$ & 7 & 6 & 5 & 210 & 3 \\
\hline Total & & & & & $945=$ & $=94,5 \%$ \\
\hline
\end{tabular}


The research aims to know Risk Priority Number (RPN) value based on the criteria of severity, occurrence, and detection. The result of RPN is of $94,5 \%=945$. The most risky first rating is on service reliability variable with RPN of 280 , the second rating is on service availability variable with RPN 245, the third rating on service availability and service performance variable is 210 respectively.

\section{E. Design of SLA (Service Level Agreement)}

This sub chapter will compile the component design from SLA document and it's weight and also calculation which result is the percentage value must be fulfilled in Academic System Information service in operation, will be discussed in table 9.

TABEL 9.

SLA VALUE DESIGN RESULT

\begin{tabular}{lll}
\hline \hline Structure & SLA Components / Elements & Weight \\
\hline & Service availability & $455=45,5 \%$ \\
& Service reliability & $280=28 \%$ \\
& Service performance & $210=21 \%$ \\
& Total & $945=94,5 \%$ \\
\hline \hline
\end{tabular}

After weight calculation each elements done, the result is $94,5 \%$ obtained for SLA value. PTIPD must fulfill this 94,5\% for SIAKAD especially when Study Plan Card (KRS) is held. The design form of the SLA document can be seen below[6], [7]:

\section{SERVICE LEVEL AGREEMENT (SLA) SIAKAD SERVICE UIN MALANG}

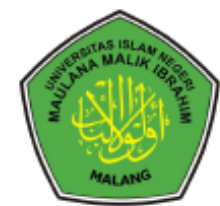

\section{PUSAT TEKNOLOGI INFORMASI DAN PANGKALAN DATA (PTIPD)} 2019

\begin{tabular}{|l|l|}
\hline Document Code: & \\
\hline Document Name: & $\begin{array}{l}\text { Service Level Agreement (SLA) SIAKAD } \\
\text { service }\end{array}$ \\
\hline Version: & 1.1 \\
\hline Revision: & 0 \\
\hline Effective Date: & \\
\hline Made by: & Staff PTIPD, \\
\hline & \\
Approved by: & Vice Chancellor III, \\
& \\
\end{tabular}

\section{Preliminary}

This document is a Service Level Agreement from SIAKAD UIN Malang service which is the reference of the PTIPD Division in providing services to students and superiors of Vice Chancellor III in the field of Student Affairs. This agreement is valid from the date set up to the next period during which this document must be reviewed by PTIPD.

\subsection{Purpose}

The purpose of this SLA Document are following

1) As a reference for SIAKAD services, especially when the KRS, in order to reduce errors that often occur.

2) As a guarantee of the service performance of PTIPD to the superior of Vice Chancellor III for Student Affairs.

\subsection{IT Service (SIAKAD)}

One of the services provided by PTIPD and as a research object is SIAKAD service. SIAKAD is a service for students to support lectures, especially when KRS, KRS is a feature to make addition / subtraction of courses to be taken by students, KRS is conducted every new semester period. twice a year within a period of one week.

\subsection{Limits and Scope}

This SLA agreement applies to SIAKAD services during KRS within one week.

1.4 Stakeholder

This Service Level Agreement is between PTIPD and Vice Chancellor III for Student Affairs.

\section{Service Level Agreement (SLA)}

2.1 Type of service

The types of services included in this service level agreement document are SIAKAD services as listed in table below, the table below contains the SLA values that must be fulfilled by PTIPD when the KRS is ruming.

\begin{tabular}{|l|l|l|l|l|l|}
\hline No & Service & $\begin{array}{c}\text { Time } \\
\text { Period }\end{array}$ & $\begin{array}{c}\text { Service } \\
\text { Availability }\end{array}$ & $\begin{array}{l}\text { Service } \\
\text { Reliability }\end{array}$ & $\begin{array}{c}\text { Service } \\
\text { Performance }\end{array}$ \\
\hline 1. & SIAKAD & $\begin{array}{l}\text { Wuring } \\
\text { KRS 1 } \\
\text { week, } \\
\text { within a }\end{array}$ & $94,5 \%$ & $\begin{array}{l}\text { week it } \\
\text { should not } \\
\text { be down } \\
\text { more than } \\
5.5 \% \text { when } \\
\text { KRS. }\end{array}$ & $\begin{array}{l}\text { Operate } \\
\text { according to } \\
\text { function } \\
\text { when KRS }\end{array}$ \\
& & & & \\
\hline
\end{tabular}

2.2 Obligation of Service Provider

PTIPD as the service provider must be responsible for ensuring that during the KRS process, the SIAKAD service above can be served at a specified time and place.

2.3 Penalty If Not Fulfilling the SLA Value

1) If the server downtime is within one week of the KRS and under the provisions of the SLA, PTIPD will get a penalty in accordance with the conditions below:

2.4 Performance Evaluation

Performance evaluations are conducted regularly to assess the performance of SIAKAD services when KRS. UIN Malang will implement a performance evaluation method periodically in 1 year, namely Internal Quality Audit (AIM). 
3. Reporting on IT Service (SIAKAD)

1) All complaints regarding SIAKAD service can be submitted to PTIPD by visiting the PTIPD office at the 2 nd floor of the rectorate building, because currently the helpdesk system is not functioning.

2) Complaint can be made when working hours at $07.00 \mathrm{am}$ until $20.00 \mathrm{pm}$ during KRS except holidays.

\section{CONCLUSION}

The conclusions of this research are as follows: Service Delivery Process area was chosen as the priority process area using the AHP method with a total weight of 1.21 and an inconsistency ratio of 0.095 . The research was continued at the stage of measuring the level of process capability of the area that provided the capability level 0 (incomplete process) results because there was no achievement of Generic Goals 1, 2 and 3 CMMI-SVC for the Service Delivery area process. The level of capability level 0 indicates that the processes in the area have not been fully implemented by the company, including the process that runs unstructured according to the procedure because there is no documented Service Level Agreement regarding services and the organizational structure does not work according to the job desk which is in the field so that when there are obstacles during the KRS, handling becomes long, because the job desk is not structured, causing the same error occurred again when the KRS.

The SLA results that PTIPD must fulfill for services are $94.5 \%$. This value is obtained from calculations using the FMEA method of several elements for the SLA.

This research produced an SLA design based ITIL V3 framework

\section{ACKNOWLEDGMENT}

Gratitude for the presence of God Almighty who always gave an extraordinary gift to the author so that the thesis entitled "Design the SLA of SIAKAD based on CMMISVC and ITIL V3 Framework (Case Study: UIN Malang) "This can be done well. This thesis is structured as a condition for fulfilling the prerequisites for completing master's study in the Technology Management Master Program, Information Technology Management Concentration, Sepuluh Nopember Institute of Technology Surabaya. The author realizes that writing this thesis will not succeed without the help and support of many parties.

\section{REFERENCES}

[1] CMMI Institute, "About CMMI," 2018. [Online]. Available: https://cmmiinstitute.com/cmmi/intro. [Accessed: 22-May2018].

[2] CMMI Institute, "CMMI Institute, CMMI for Service," 2018. [Online]. Available: https://cmmiinstitute.com/cmmi/svc. [Accessed: 22-May-2018].

[3] A. Cartlidge et al., An Introduction Overview of ITIL 2011. TSO (The Stationery Office), 2013.

[4] A. Hidapratiwi and A. Djunaidy, "Desain service level agreement untuk layanan TI/ SI di Politeknik Telkom menggunakan Information Technology Infrastructure Llibrary (ITIL)," in Prosiding Seminar Nasional Manajemen Teknologi XVI, 2012, p. C.22.1-C.22.8.

[5] H. Hasbullah, M. Kholil, and D. A. Santoso, "Analisa kegagalan proses insulasi pada produksi Automotive Wires (AW) dengan metode Failure Mode and Effect Analysis (FMEA) pada PT. JLC," SINERGI, vol. 21, no. 3, p. 193, Nov. 2017.

[6] UPT-TIK Universitas Pendidikan Ganesha, Helpdesk Service Level Agreement (SLA) UPT-TIK Universitas Pendidikan Ganesha. Universitas Pendidikan Ganesha.

[7] LP3 Universitas Brawijaya, Service Level Agreement (SLA) Layanan Jurnal Erudio untuk Ilmuwan di Bidang Ilmu Pendidikan. Universitas Brawijaya, 2015. 